\title{
The dumortierite supergroup. I. A new nomenclature for the dumortierite and holtite groups
}

\author{
A. Pieczka ${ }^{1} *$, R. J. Evans ${ }^{2}$, E. S. Grew ${ }^{3}$, L. A. Groat ${ }^{2}$, C. $\mathrm{MA}^{4}$ and G. R. Rossman ${ }^{4}$
}

1 Department of Mineralogy, Petrography and Geochemistry, AGH-University of Science and Technology, Mickiewicza 30, Kraków, 30-059, Poland

2 Department of Earth, Ocean and Atmospheric Sciences, University of British Columbia, 6339 Stores Road, Vancouver, British Columbia, V6T IZ4, Canada

3 School of Earth and Climate Sciences, University of Maine, Bryand Global Science Center, Orono, Maine, 044695790, USA

4 Division of Geological and Planetary Sciences, California Institute of Technology, MS 170-25, Pasadena, California, 91125-2500, USA

[Received 26 December 2013; Accepted 11 July 2013; Associate Editor: A. Christy]

\section{ABSTRACT}

Although the distinction between magnesiodumortieite and dumortierite, i.e. $\mathrm{Mg} v s$. Al dominance at the partially vacant octahedral All site, had met current criteria of the IMA Commission on New Minerals, Nomenclature and Classification (CNMNC) for distinguishing mineral species, the distinction between holtite and dumortierite had not, since $\mathrm{Al}$ and $\mathrm{Si}$ are dominant over $\mathrm{Ta}$ and (Sb,As) at the Al1 and two Si sites, respectively, in both minerals. Recent studies have revealed extensive solid solution between $\mathrm{Al}, \mathrm{Ti}, \mathrm{Ta}$ and $\mathrm{Nb}$ at All and between $\mathrm{Si}, \mathrm{As}$ and $\mathrm{Sb}$ at the two Si sites or nearly coincident $(\mathrm{As}, \mathrm{Sb})$ sites in dumortierite and holtite, further blurring the distinction between the two minerals.

This situation necessitated revision in the nomenclature of the dumortierite group. The newly constituted dumortierite supergroup, space group Pnma (no. 62), comprises two groups and six minerals, one of which is the first member of a potential third group, all isostructural with dumortierite. The supergroup, which has been approved by the CNMNC, is based on more specific end-member compositions for dumortierite and holtite, in which occupancy of the All site is critical.

(1) Dumortierite group, with $\mathrm{All}=\mathrm{Al}^{3+}, \mathrm{Mg}^{2+}$ and $\square$, where $\square$ denotes cation vacancy. Charge balance is provided by $\mathrm{OH}$ substitution for $\mathrm{O}$ at the $\mathrm{O} 2, \mathrm{O} 7$ and $\mathrm{O} 10$ sites. In addition to dumortierite, endmember composition $\mathrm{AlAl}_{6} \mathrm{BSi}_{3} \mathrm{O}_{18}$, and magnesiodumortierite, endmember composition $\mathrm{MgAl}_{6} \mathrm{BSi}_{3} \mathrm{O}_{17}(\mathrm{OH})$, plus three endmembers, "hydroxydumortierite", $\square \mathrm{Al}_{6} \mathrm{BSi}_{3} \mathrm{O}_{15}(\mathrm{OH})_{3}$ and two $\mathrm{Mg}$-Ti analogues of dumortierite, $\left(\mathrm{Mg}_{0.5} \mathrm{Ti}_{0.5}\right) \mathrm{Al}_{6} \mathrm{BSi}_{3} \mathrm{O}_{18}$ and $\left(\mathrm{Mg}_{0.5} \mathrm{Ti}_{0.5}\right) \mathrm{Mg}_{2} \mathrm{Al}_{4} \mathrm{BSi}_{3} \mathrm{O}_{16}(\mathrm{OH})_{2}$, none of which correspond to mineral species. Three more hypothetical endmembers are derived by homovalent substitutions of $\mathrm{Fe}^{3+}$ for $\mathrm{Al}$ and $\mathrm{Fe}^{2+}$ for $\mathrm{Mg}$.

(2) Holtite group, with $\mathrm{All}=\mathrm{Ta}^{5+}, \mathrm{Nb}^{5+}, \mathrm{Ti}^{4+}$ and $\square$. In contrast to the dumortierite group, vacancies serve not only to balance the extra charge introduced by the incorporation of pentavalent and quadrivalent cations for trivalent cations at Al1, but also to reduce repulsion between the highly charged cations. This group includes holtite, endmember composition $\left(\mathrm{Ta}_{0.6} \square 0.4\right) \mathrm{Al}_{6} \mathrm{BSi}_{3} \mathrm{O}_{18}$, nioboholite (2012-68), endmember composition $\left(\mathrm{Nb}_{0.6} \square_{0.4}\right) \mathrm{Al}_{6} \mathrm{BSi}_{3} \mathrm{O}_{18}$, and titanoholtite (2012-69), endmember composition $\left(\mathrm{Ti}_{0.75} \square_{0.25}\right) \mathrm{Al}_{6} \mathrm{BSi}_{3} \mathrm{O}_{18}$.

(3) Szklaryite (2012-70) with Al1 $=\square$ and an endmember formula $\square \mathrm{Al}_{6} \mathrm{BAs}_{3}^{3+} \mathrm{O}_{15}$. Vacancies at All are caused by loss of $\mathrm{O}$ at $\mathrm{O} 2$ and $\mathrm{O} 7$, which coordinate the All with the Si sites, due to

* E-mail: pieczka@agh.edu.pl

DOI: 10.1180/minmag.2013.077.6.09 
replacement of $\mathrm{Si}^{4+}$ by $\mathrm{As}^{3+}$ and $\mathrm{Sb}^{3+}$, and thus this mineral does not belong in either the dumortierite or the holtite group. Although szklaryite is distinguished by the mechanism introducing vacancies at the All site, the primary criterion for identifying it is based on occupancy of the Si/As,Sb sites: $\left(\mathrm{As}^{3+}+\right.$ $\left.\mathrm{Sb}^{3+}\right)>\mathrm{Si}^{4+}$ consistent with the dominant-valency rule. $\mathrm{A} \mathrm{Sb}^{3+}$ analogue to szklaryite is possible.

KEYWORDs: dumortierite group, holtite group, nioboholtite, titanoholtite, szklaryite, nomenclature, crystal chemistry.

\section{Introduction}

As presently constituted, the dumortierite group comprises three minerals: dumortierite, $(\mathrm{Al}, \square) \mathrm{Al}_{6} \mathrm{BSi}_{3} \mathrm{O}_{16}(\mathrm{O}, \mathrm{OH})_{2}$, magnesiodumortierite, $(\mathrm{Mg}, \square) \mathrm{Al}_{6} \mathrm{BSi}_{3} \mathrm{O}_{16}(\mathrm{O}, \mathrm{OH})_{2}$, and holtite, $(\mathrm{A} 1, \mathrm{Ta}, \square) \mathrm{Al}_{6} \mathrm{~B}(\mathrm{Si}, \mathrm{Sb}, \mathrm{As})_{\Sigma 3} \mathrm{O}_{15}(\mathrm{O}, \mathrm{OH}, \square)_{\Sigma 3}$, where $\square$ denotes cation or anion vacancy. Dumortierite is second only to tourmaline-supergroup minerals as the most abundant B-bearing phase in metamorphosed pelitic and psammitic rocks, aluminous metasomatic rocks and granitic plutonic rocks (Grew, 2002). It was first reported in 1880 from pegmatitic veins near Lyon, France (Bertrand, 1880; Gonnard, 1881), and named for the French palaeontologist Eugène Dumortier. It took many years for the full complexity of dumortierite chemistry to be revealed, e.g. that it contains essential B (Schaller, 1905), and that its cation and $\mathrm{OH}$ contents are non-stoichiometric (Golovastikov, 1965; Moore and Araki, 1978). Until about 1995, $\mathrm{P}_{2} \mathrm{O}_{5}, \mathrm{MgO}, \mathrm{TiO}_{2}, \mathrm{Fe}_{2} \mathrm{O}_{3}$ and $\mathrm{FeO}$ were thought to be the most abundant constituents other than $\mathrm{H}_{2} \mathrm{O}, \mathrm{B}_{2} \mathrm{O}_{3}, \mathrm{Al}_{2} \mathrm{O}_{3}$ and $\mathrm{SiO}_{2}$ (Grew, 2002), but more recent work has shown that $\mathrm{As}_{2} \mathrm{O}_{3}, \mathrm{Sb}_{2} \mathrm{O}_{3}, \mathrm{Ta}_{2} \mathrm{O}_{5}$ and $\mathrm{Nb}_{2} \mathrm{O}_{5}$ are also present in substantial quantities, and a few samples contain $\mathrm{Bi}$, presumably as $\mathrm{Bi}^{3+}$ (e.g. Groat et al., 2001, 2012; Cempírek and Novák, 2005; Borghi et al., 2004; Vaggelli et al., 2004; Cempírek et al., 2010; Pieczka et al., 2011).

Magnesiodumortierite was reported as the Mgdominant analogue of dumortierite from ultrahigh-pressure rocks at Dora Maira in the Italian Alps (Chopin et al., 1995; Ferraris et al., 1995). The most magnesian compositions reported by Visser and Senior (1991 and unpublished data) and by Kihle (1989 and unpublished data) in dumortierite from the Bamble Sector, Norway, might also qualify as magnesiodumortierite (Chopin et al., 1995; Grew, 2002), but to date no other occurrence has been reported.

Holtite was first described from alluvial deposits formed from pegmatite at Greenbushes, Western Australia (Pryce, 1971) and named for
Harold E. Holt, Prime Minister of Australia from 1966 to 1967 , and its crystal structure refined by Hoskins et al. (1989). It is known only from complex granitic pegmatites, having been reported from three other localities: Voron'i Tundry, Kola Peninsula, Russia (Voloshin et al., 1977; 1987; Voloshin and Pakhomovskiy, 1988); Szklary, Lower Silesia, Poland (Pieczka and Marszałek, 1996; Pieczka et al., 2011), and Virorco, San Luis range, Argentina (Galliski et al., 2012). In contrast to the situation for many new minerals described in the last 50 years, none of the four constituents that distinguish holtite from dumortierite is dominant at a specific crystallographic site, e.g. $\mathrm{Si}$ is dominant over $\mathrm{Sb}^{3+}$ and $\mathrm{As}^{3+}$ at the two tetrahedral sites and $\mathrm{Al}$ is dominant over $\mathrm{Ta}, \mathrm{Nb}$ and vacancy at the Al1 site in both minerals. Voloshin et al. $(1977,1987)$ introduced the terms "holtite I" and "holtite II" for clusters of holtite compositions differing in $(\mathrm{As}+\mathrm{Sb})$ content, but compositions from other localities, particularly the Szklary pegmatite, filled the apparent gap between the two compositions (Pieczka et al., 2011). Groat et al. (2009) suggested the clustering could be an artifact resulting from there being two generations of holtite formed in different chemical environments at Voron'i Tundry, rather than from a crystallographic control. Moreover, the compositional range in holtite from the Szklary pegmatite extended to higher $(\mathrm{Sb}+\mathrm{As})$ contents than the high ( $\mathrm{Sb}+\mathrm{As})$ composition of "holtite II" (Pieczka et al., 2011).

In the absence of a rigorous definition, the term holtite was being applied indiscriminately to an ever-widening compositional range, while dumortierite was found to contain substantial amounts of the elements that supposedly distinguish holtite from dumortierite. The end result is that distinction between holtite and dumortierite has become blurred, and consequently, we are recommending a new classification of the dumortierite group in which the minerals are distinguished on the basis of crystal chemistry and consistently with current CNMNC practice. 


\section{Crystal structure of dumortierite and related minerals}

The crystal structure of dumortierite (Fig. 1), space group Pnma (no. 62), was described by Golovastikov (1965) and Moore and Araki (1978) as a design on the semi-regular planar net $\{6 \cdot 4 \cdot 3 \cdot 4\}$, which Moore and Araki (1978) showed can be broken down into four regions: (1) $\left[\mathrm{AlO}_{3}\right]$ chains of face-sharing octahedra (the Al1 sites) with circumjacent "pinwheels" of six $\mathrm{SiO}_{4}$ tetrahedra, two $\mathrm{Si} 1$ and four $\mathrm{Si} 2$ sites; (2) $\left[\mathrm{Al}_{4} \mathrm{O}_{12}\right]$ cubic close-packed chains parallel to the [100] direction, containing the Al2 and Al3 octahedral sites, that are joined to equivalent chains by reflection at the $\mathrm{O} 1$ corners of the $\mathrm{Al} 2$ octahedra to form $\left[\mathrm{Al}_{4} \mathrm{O}_{11}\right]$ sheets oriented parallel to (001); (3) $\left[\mathrm{Al}_{4} \mathrm{O}_{12}\right]$ double-chains parallel to the [100] direction containing the A14 octahedral sites with some face-sharing; and (4) $\mathrm{BO}_{3}$ triangles. The Al1-All distance is $\sim 2.35 \AA$, which is unusually short for facesharing octahedra, and the All site is on average $75 \%$ occupied by $\mathrm{Al}$ (e.g. Moore and Araki, 1978). The All face-sharing chains are disor- dered, which results in an average chain length that can be adjusted to fit the repeat distance of the remaining octahedral framework in the structure (Moore and Araki, 1978). Evans et al. (2012) reported that when there is minor substitution for $\mathrm{Al}$ at $\mathrm{All}$, three distinct sub-sites of All could be distinguished depending on which adjacent All sites were occupied; each sub-site was found to be $\sim 1 / 4$ occupied. Such ordering would not be expected in compositions with more substitution at All. Although Al cations in individual face-sharing All octahedral chains are ordered, cations from chain to chain are disordered, preserving Pnma symmetry.

Groat et al. (2012) reported splitting of the two (As, Sb) sites into four distinct As1, Sb1, As2 and Sb2 positions, and the single A11 site split into three Alla, All and Allb positions whose occupancies refined to All $>$ Alla $>$ Allb in dumortierite containing a significant amount of $\mathrm{As}$ and $\mathrm{Sb}$, but relatively little $\mathrm{Ta}$ and $\mathrm{Nb}$. The unequal occupancies suggest that the hexagonal tunnels contain a disordered mix of face-sharing octahedral dimers, trimers and longer units separated by vacancies. The splitting does not

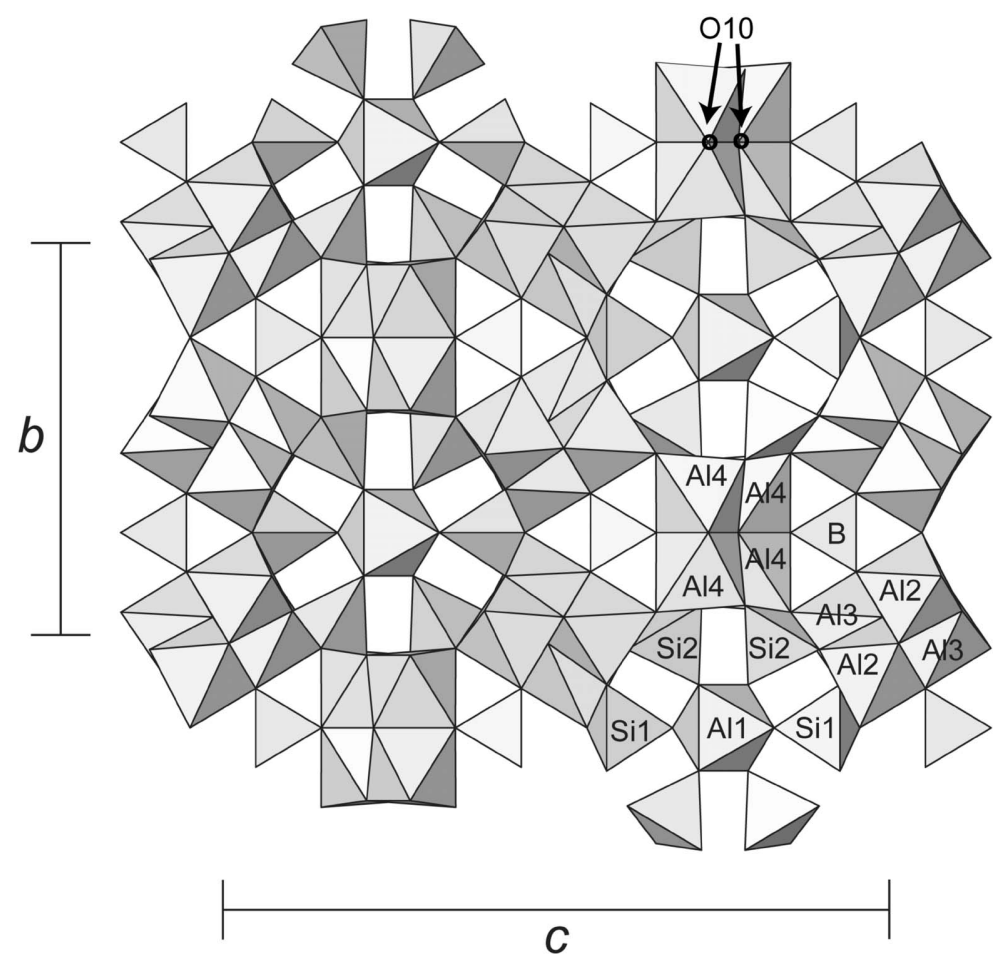

FIG. 1. The crystal structure of dumortierite viewed down the $a$ axis. Pnma setting (from Groat et al., 2009, 2012). 
result in a superstructure, which was reported in a dumortierite-like mineral found as fibres in rose quartz (Applin and Hicks, 1987; Goreva et al., 2001; Ma et al., 2002). This mineral differs from dumortierite in having a superstructure with the $b$ and $c$ dimensions doubled (Pnma orientation), which Ma et al. (2002) attributed to ordering of Ti and Fe at "Type II" All sites and Al at "Type I" A11 sites with "Type I" and "Type II" having a regular distribution in (100). Ma et al. (2002) reported that $(\mathrm{Fe}+\mathrm{Ti})$ ranged from 0.28 to 0.34 a.p.f.u. (18 $\mathrm{O}$ basis), which is above average, but within the reported range for dumortierite (Grew, 2002). Thus, the ordering could be related to the relatively low temperatures of exsolution of the fibres from quartz as Ma et al. (2002) suggested, and not to composition.

In magnesiodumortierite, $\mathrm{Mg}$ substitutes for $\mathrm{Al}$ at the All and Al4 sites, but Mg > Al only at Al1 (Chopin et al., 1995; Ferraris et al., 1995). Hydroxyl in dumortierite and magnesiodumortierite is thought to occur at the $\mathrm{O} 2$ and $\mathrm{O} 7$ positions (e.g. Moore and Araki, 1978; Alexander et al., 1986; Cempírek and Novák, 2005; Fuchs et al., 2005), and at the four-coordinate $\mathrm{O} 10$ site (Ferraris et al., 1995; Farges et al., 2004).

Hoskins et al. (1989) showed that the crystal structure of holtite is closely related to that of dumortierite, but differs in several important respects, all of which lie within six-sided tunnels bounded by the two regions composed of $\left[\mathrm{Al}_{4} \mathrm{O}_{12}\right]$ chains (Fig. 1). Both $\mathrm{SiO}_{4}$ tetrahedra are replaced partially by $\mathrm{Sb}^{3+} \mathrm{O}_{3}$ triangular pyramids $\left(\mathrm{As}^{3+}\right.$ is dominant at this site in szklaryite, Fig. 2) with no evidence of preference of $\mathrm{Sb}$ for one of the $\mathrm{Si}$ sites, and Ta replaces $\mathrm{Al}$ at the All position. As a result, there are vacancies at the coordinating anion sites (O2 and O7) as well as at the All site. Relative to the Si positions, the $\mathrm{Sb}^{3+}$ sites are shifted $\sim 0.5 \AA$ closer to the Al1 position to accommodate the longer $\mathrm{Sb}^{3+}$-anion bonds (average $\sim 1.9 \AA$ ). When the $\mathrm{Sb}$ sites are occupied, O2 (for Si1) and O7 (for Si2) positions are vacant. Hoskins et al. (1989) obtained the formula $\left(\mathrm{Si}_{2.25} \mathrm{Sb}_{0.75}\right) \mathrm{B}\left[\mathrm{Al}_{6}\left(\mathrm{Al}_{0.43} \mathrm{Ta}_{0.27} \square_{0.30}\right)\right.$ $\left.\mathrm{O}_{15}(\mathrm{O}, \mathrm{OH})_{2.25}\right](\mathrm{Z}=4)$ from their crystalstructure study. Even for zero $\mathrm{OH}$ content, this formula has an excess positive charge of +0.39 . Kazantsev et al. $(2005,2006)$ refined the crystal structure of an As-bearing "holtite I" crystal from Voron'i Tundry to $R=0.046$. They reported that $\mathrm{As}^{3+}$ is incorporated into the crystal structure in $(\mathrm{Sb}, \mathrm{As}) \mathrm{O}_{3}$ pyramids substituting for $\mathrm{SiO}_{4}$ tetrahedra just as $\mathrm{SbO}_{3}$ pyramids substitute for $\mathrm{SiO}_{4}$ tetrahedra in holtite from Greenbushes, and there was no preference for one of the two Si positions. In their refinement of four holtite crystals, Groat et al. (2009) reported that charge-balance calculations suggest that essentially no water is present, but that Fourier transform infrared

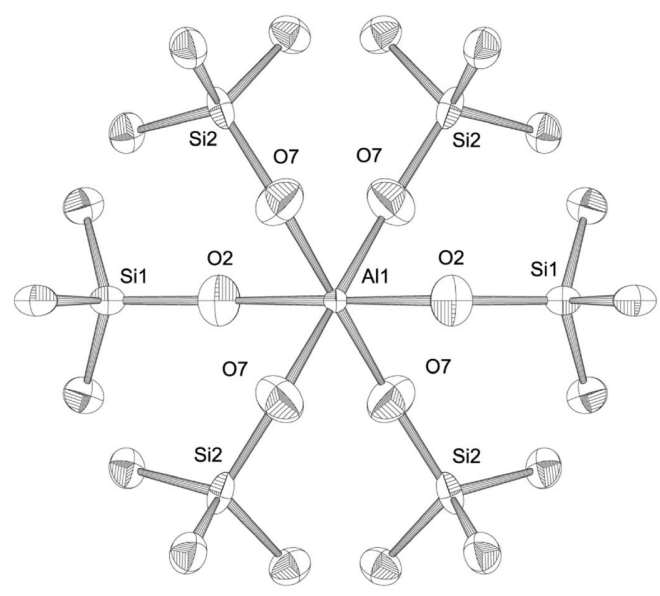

Dumortierite (holtite in part)

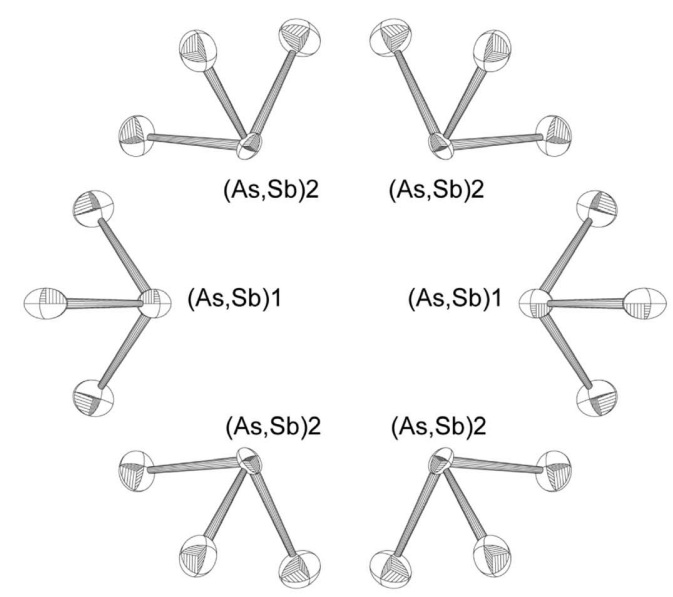

Szklaryite (holtite in part)

FIG. 2. The six-sided tunnels (region 1 of Moore and Araki, 1978) filled with All octahedra and $\mathrm{SiO}_{4}$ tetrahedra in dumortierite, $(\mathrm{As}, \mathrm{Sb}) \mathrm{O}_{3}$ groups in the new mineral szklaryite, or a mixture of $(\mathrm{Sb}, \mathrm{As}) \mathrm{O}_{3}$ groups and $\mathrm{SiO}_{4}$ tetrahedra in holtite (after Hoskins et al., 1989; Groat et al., 2009, 2012). Al1 is largely vacant in szklaryite. 
spectra confirm that some $\mathrm{OH}$ is present at the $\mathrm{O} 2$ and $\mathrm{O} 7$ positions. Their proposed general formula for holtite is $\mathrm{Al}_{7-[5 x+y+z] / 3}(\mathrm{Ta}, \mathrm{Nb})_{x} \square_{[2 x+y+z] / 3} \mathrm{~B}$ $\mathrm{Si}_{3-y}(\mathrm{Sb}, \mathrm{As})_{y} \mathrm{O}_{18-y-z}(\mathrm{OH})_{z}$, where $x$ is the total number of pentavalent cations, $y$ is the total amount of $\mathrm{Sb}+$ As and $z \leqslant y$ is the total amount of $\mathrm{OH}$. The splitting of (Sb, As) and All sites observed in dumortierite has not been found in holtite (Groat et al., 2012).

In crystallographic studies of dumortierite, magnesiodumortierite and holtite, $\mathrm{B}$ has been reported to occupy only the trigonal site, which is confirmed by study of B $K$-edge spectra (Garvie et al., 1995; Fleet and Muthupari, 2000). No evidence for deviation from stoichiometry been reported for B in the crystal structure refinements, which is consistent with B contents reported in synthetic dumortierite by Werding and Schreyer (1990; cf. Ono 1981). Chemical determination of B content is difficult both by wet methods, because dumortierite supergroup minerals are often finely fibrous and impure, and by electron or ion microprobe because of problems with matrix correction and standardization. Thus, it is not surprising that a wide range of $\mathrm{B}$ contents has been reported, e.g. the non-stoichiometric B content obtained by wet chemical analysis in type holtite, 1.82 wt. $\% \mathrm{~B}_{2} \mathrm{O}_{3}$ (Pryce, 1971), which was later shown to be in error by single-crystal refinement (Hoskins et al., 1989). In other cases, B contents less deviant from stoichiometry, or even approaching it, were reported using wet chemical (e.g. Claringbull and Hey, 1952; Voloshin et al., 1977; Chopin et al., 1995), ion microprobe (Willner and Schreyer, 1991), and electron microprobe analyses (Vrána, 1979; Chopin et al., 1995; Fuchs et al., 2005; Pieczka et al., 2013), but the precision was too low to properly assess whether the observed deviations are significant.

\section{Relationship to ellenbergerite, phosphoellenbergerite and ekatite}

Dumortierite supergroup minerals have a strong structural affinity with the isotypic hexagonal species ellenbergerite, phosphoellenbergerite and ekatite. Moore and Araki (1978) implied that transformation of the orthorhombic dumortierite into a hexagonal dimorph might be relatively simple in principle. However, as pointed out by Ferraris et al. (1995) (and later by Keller, 2001, and Evans and Groat, 2012), transformation of dumortierite into an ellenbergerite-type hexagonal polymorph "would be far from straightforward," and thus including these three minerals in the dumortierite supergroup is not warranted. Evans and Groat (2012) grouped the dumortierite supergroup, ellenbergerite, phosphoellenbergerite, ekatite and a host of synthetic compounds together as "dumortierite-like materials."

We agree with Ferraris et al. (1995) and Keller (2001) that the differences are significant enough that ellenbergerite, phosphoellenbergerite and ekatite should remain separate from the dumortierite supergroup. Ferraris et al. (1995) emphasized that the difference in the two structures involves more than simply replacing $\mathrm{Al} 2-\mathrm{Al} 3$ chains in dumortierite with copies of the Al4 chains. The tetrahedral groups in each hexagonal channel give the channel a defined orientation. Ferraris et al. (1995) described how both the dumortierite and ellenbergerite structures can be decomposed into slabs parallel to the $\left[\mathrm{Al}_{4} \mathrm{O}_{11}\right]$ sheets. In the hexagonal structure, hexagonal channels have the same orientation in every slab, whereas in the orthorhombic structure, the hexagonal channels reverse orientations every other slab. The A12-A13-type chains show similar alternating orientations. Ferraris et al. (1995) argued that this made an orthorhombic-tohexagonal transition in dumortierite unlikely, as such a transition would involve inverting half the structure. There is also a significant difference in the triangular channels. The triangular channel in all the dumortierite supergroup minerals contains only trigonal-planar borate groups, whereas the minerals related to ellenbergerite each contain multiple tetrahedral or pyramidal groups: silicate and phosphate in ellenbergerite (Chopin et al., 1986); phosphate and (trigonal planar) carbonate in phosphoellenbergerite (Raade et al., 1998); and silicate and arsenite in ekatite (Keller, 2001). The lack of any known substitution at the B site in dumortierite minerals is very distinctive and might be related to the other differences between the dumortierite and ellenbergerite structures, the latter of which appears to incorporate negligible B: Ferraris et al. (1995) considered it significant that ellenbergerite found in contact with magnesiodumortierite contains only 10 ppm B.

\section{Nomenclature of the dumortierite supergroup}

The new classification for the dumortierite group has been approved by the IMA Commission on 
A. PIECZKA ET AL.

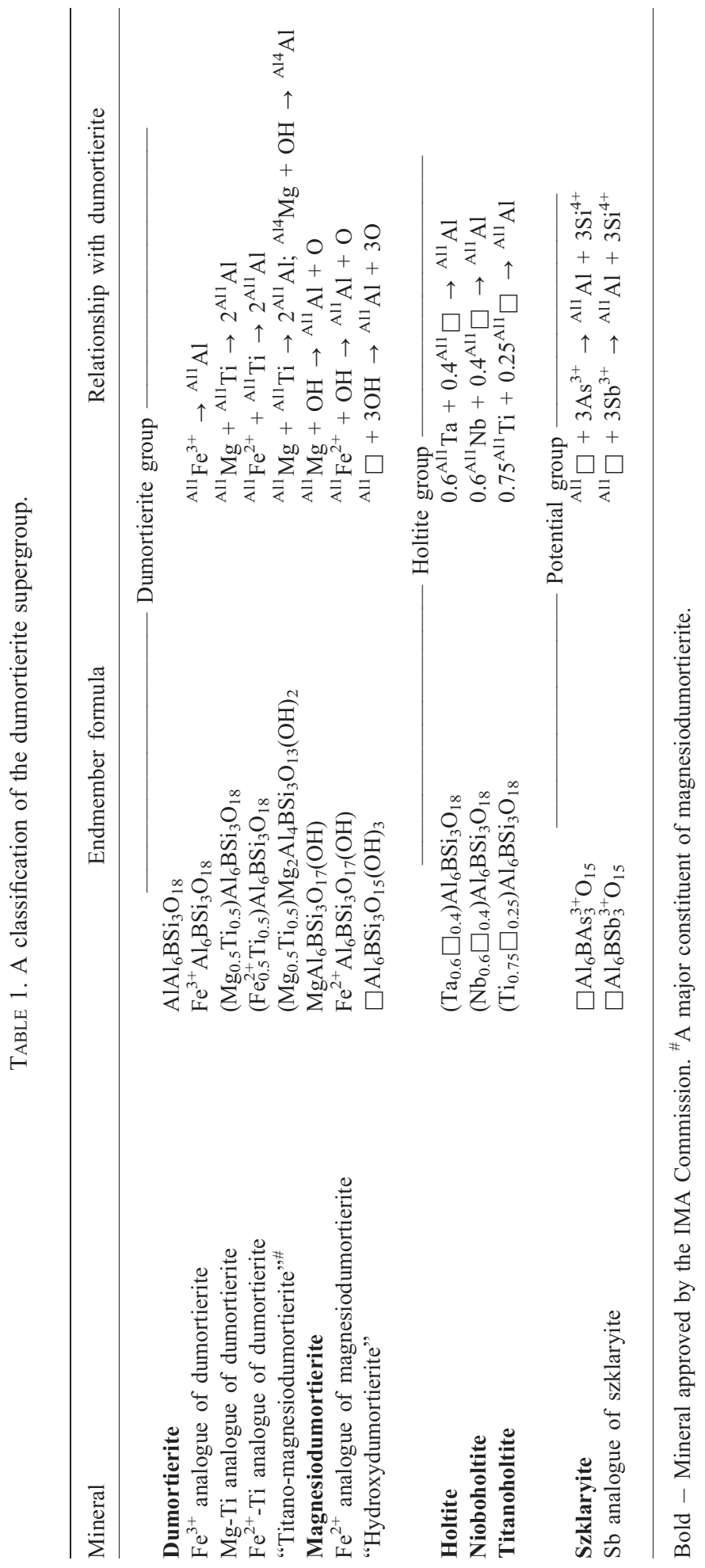


New Minerals, Nomenclature and Classification (CNMNC proposal 12-C, November 6, 2012). The group is now considered a supergroup as it can be subdivided into three groups (one is potential as only one representative has been found to date) on the basis of the differences in the substitution mechanisms that decrease occupancy at the All site, which is the basis of the classification (Table 1, Fig. 3). It is important to note that up to $5 \%$ vacancies have been reported at the other three octahedral Al sites, which are generally believed to be real (e.g. Fuchs et al., 2005; Groat et al., 2012), although Moore and Araki (1978) and Alexander et al. (1986) inferred that vacancies at these sites resulted from correlation between the site occupancies and atomic displacement parameters. In addition, $\mathrm{Mg}$ substitution for $\mathrm{Al}$ at $\mathrm{Al} 4$ is reported for magnesiodumortierite, ${ }^{\mathrm{Al} 4} \mathrm{Mg}+\mathrm{OH} \rightarrow{ }^{\mathrm{Al} 4} \mathrm{Al}+$ O (Chopin et al., 1995; Ferraris et al., 1995). However, for the purposes of the classification we only consider the All site because Al is overwhelmingly dominant at the other Al sites, excepting the $\sim 50 \% \mathrm{Al}$ at $\mathrm{Al} 4$ in Ti-rich magnesiodumortierite (Chopin et al., 1995; Ferraris et al., 1995).

We have identified three distinct mechanisms for introducing vacancies at All, which gives us two groups and a potential group:

(1) Dumortierite group: Charge-balance for vacancies at $\mathrm{All}$ is provided by $\mathrm{OH}$ substitution for $\mathrm{O}$ at the $\mathrm{O} 2, \mathrm{O} 7$ and $\mathrm{O} 10$ sites.
(2) Holtite group: Vacancies serve not only to balance the extra charge introduced by the incorporation of pentavalent and quadrivalent cations for trivalent cations at Al1, but also to reduce repulsion between the highly charged cations.

(3) Potential group including szklaryite. Vacancies at A11 are caused by loss of $\mathrm{O} 2$ and O7, which coordinate the All with the Si sites, due to replacement of $\mathrm{Si}^{4+}$ by $\mathrm{As}^{3+}$ and $\mathrm{Sb}^{3+}$, and thus this mineral does not belong in either the dumortierite or the holtite group. $\mathrm{An} \mathrm{Sb}^{3+}$ analogue to szklaryite is possible.

\section{Dumortierite group}

The dumortierite group includes eight endmembers (Table 1), two of which are major constituents of naturally occurring minerals: dumortierite, endmember composition $\mathrm{AlAl}_{6} \mathrm{BSi}_{3} \mathrm{O}_{18}$, and magnesiodumortierite, endmember composition $\mathrm{MgAl}_{6} \mathrm{BSi}_{3} \mathrm{O}_{17}(\mathrm{OH})$ (Fig. 4). In general, classification of the dumortierite group follows the dominant-valency rule (Hatert and Burke, 2008) as the formulae given for three corners of the tetrahedron represent different valences at the All site, i.e. $0(\square), 2\left(\mathrm{Mg}, \mathrm{Fe}^{2+}\right)$ and $3\left(\mathrm{Al}, \mathrm{Fe}^{3+}\right)$, whereas the fourth corner $\left(\mathrm{Mg}, \mathrm{Fe}^{2+}\right)_{0.5} \mathrm{Ti}_{0.5}$ can be considered a case of valency-imposed double siteoccupancy.

The All site has not been reported to be fully occupied by Al, the maximum occupancy being

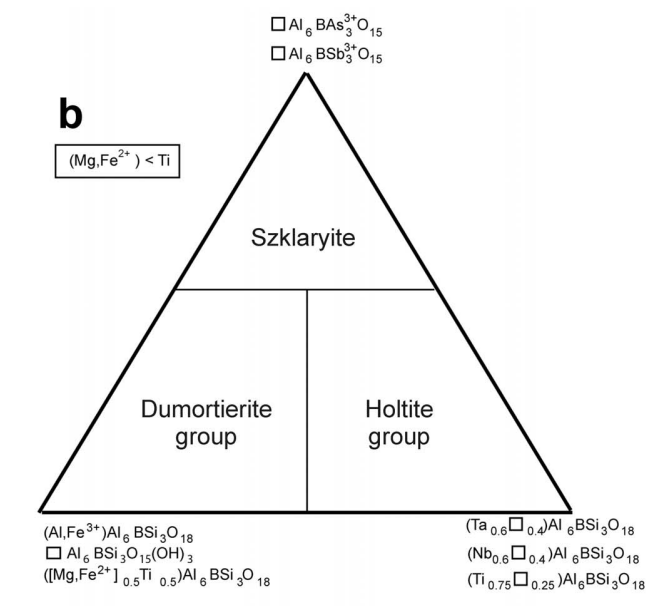

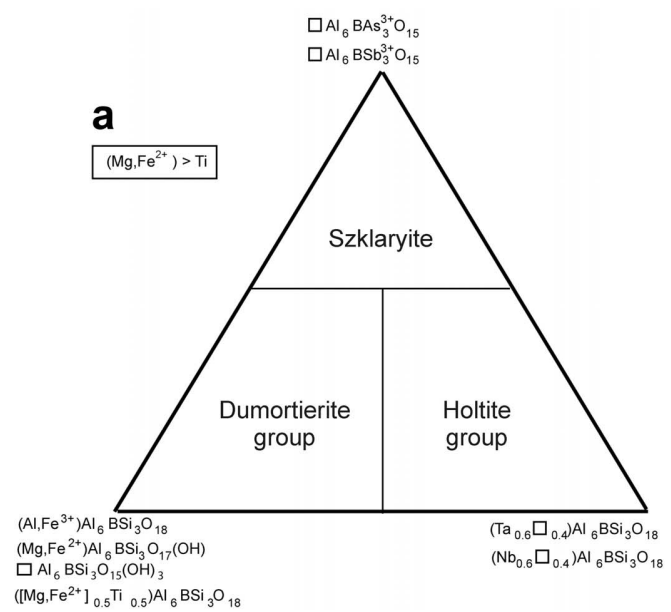

FIG. 3. Subdivision of the dumortierite supergroup into two groups and one potential group on the basis of Al1 occupancy. $\mathrm{Fe}^{3+}$ is added to $\mathrm{Al}$ and $\mathrm{Fe}^{2+}$ to $\mathrm{Mg}$. Ti is considered a constituent of dumortierite only if coupled with $\mathrm{Mg}$ and $\mathrm{Fe}^{2+}$. 


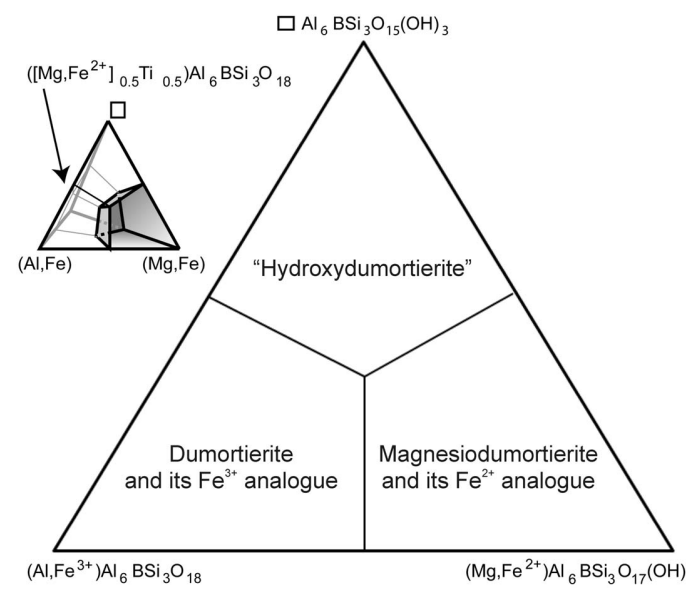

FIG. 4. By combining $\mathrm{Fe}$ with $\mathrm{Al}$ and $\mathrm{Mg}$, the dumortierite group can be represented by a fourcomponent system (inset) with most compositional variation in the Ti-free system (triangle), where two recognized minerals and one hypothetical component are recognized on the basis of All occupancy.

88\% (Alexander et al., 1986, not including their 0.95 empirical correction; Groat et al., 2012), and it appears that the dumortierite endmember $\mathrm{AlAl}_{6} \mathrm{BSi}_{3} \mathrm{O}_{18}$ is unattainable due to face-sharing in the chain of All octahedra. Instead, all naturally occurring dumortierite is a mixture of this composition with others, most commonly, the "'hydroxydumortierite", component, $\square \mathrm{Al}_{6} \mathrm{BSi}_{3} \mathrm{O}_{15}(\mathrm{OH})_{3}$ (Moore and Araki, 1978), which Werding and Schreyer (1990) cited as constituting up to $33 \%$ of dumortierite synthesized at pressures from 3 to $20 \mathrm{kbar}$ in the $\mathrm{Al}_{2} \mathrm{O}_{3}-$ $\mathrm{SiO}_{2}-\mathrm{B}_{2} \mathrm{O}_{3}-\mathrm{H}_{2} \mathrm{O}$ system. Natural dumortierite with relatively few impurities is estimated to contain $<30 \% \quad \square \mathrm{Al}_{6} \mathrm{BSi}_{3} \mathrm{O}_{15}(\mathrm{OH})_{3}$ (Moore and Araki, 1978; Alexander et al., 1986; Cempírek and Novák, 2005; Fuchs et al., 2005).

Except for magnesiodumortierite from the type locality, Dora Maira, the maximum $\mathrm{MgO}$ content of 3.42 wt.\% was reported by Visser and Senior (1991) in a dumortierite from the Bamble Sector, Norway. Assuming $\mathrm{OH}=0.75$ per $18 \mathrm{O}$, the composition of this dumortierite gives an All occupancy corresponding in endmembers to $45 \%$ magnesiodumortierite, $37 \%$ dumortierite, 5\% $\left(\mathrm{Mg}_{0.5} \mathrm{Ti}_{0.5}\right) \mathrm{Al}_{6} \mathrm{BSi}_{3} \mathrm{O}_{18}, 5 \%$ of an Fe endmember and $7 \% \quad \square \mathrm{Al}_{6} \mathrm{BSi}_{3} \mathrm{O}_{15}(\mathrm{OH})_{3}$, i.e. magnesiodumortierite is dominant whether $\mathrm{Fe}$ is ferrous or ferric. However, the calculated proportions are sensitive to the assumed $\mathrm{OH}$ content, e.g. for $\mathrm{OH}$
$=0.6$ per $18 \mathrm{O}$ and $\mathrm{Fe}$ assumed to be $\mathrm{Fe}^{3+}$ and added to dumortierite (dominant-valency rule), the magnesiodumortierite endmember is no longer dominant. Several other dumortierite samples from the Bamble Sector contain $>3$ wt.\% MgO (Visser and Senior, 1991 and unpublished data; Kihle, 1989 and unpublished data), and formulae give nearly equal proportions of the magnesiodumortierite and dumortierite endmembers. As compositions straddle the boundary between the two minerals, determining whether any dumortierite from the Bamble Sector is magnesiodumortierite would require precise measurements of water content and iron valence.

Iron contents of dumortierite-group minerals range from 0 to 5.94 wt. $\% \mathrm{Fe}$ as $\mathrm{Fe}_{2} \mathrm{O}_{3}$ (Claringbull and Hey, 1958; Grew, 2002; Groat and Evans, unpublished data), but determining its valence requires wet chemistry (titrations) or a spectroscopic method. Platonov et al. (2000) attributed the marked blue, violet and red coloration and pleochroism to $\mathrm{Fe}^{2+}-\mathrm{Ti}^{4+}$ intervalence charge transfer with little, if any contribution from $\mathrm{Fe}^{2+}-\mathrm{Fe}^{3+}$ charge transfer, whereas Goreva and Rossman (2000) found evidence that pink and blue colours were due to $\mathrm{Fe}^{2+}-\mathrm{Ti}^{4+}$ intervalence charge transfer and $\mathrm{Fe}^{2+}-\mathrm{Fe}^{3+}$ intervalence charge transfer, respectively, in nano-inclusions of a dumortierite-like phase in quartz, consistent with the findings that $\mathrm{Fe}^{3+}$ is also involved in coloring dumortierite (Alexander et al., 1986; Farges et al., 2004; Fuchs et al., 2004). Mössbauer spectroscopy also shows that both $\mathrm{Fe}^{2+}$ and $\mathrm{Fe}^{3+}$ are present in dumortierite (Farges et al., 2004). Thus, three endmembers involving homovalent substitutions of $\mathrm{Fe}^{3+}$ and $\mathrm{Fe}^{2+}$ for ${ }^{\mathrm{All}} \mathrm{Al}$ and ${ }^{\mathrm{All}} \mathrm{Mg}$, respectively, are theoretically possible (Table 1), although the Fe contents of natural material are never sufficient for an $\mathrm{Fe}$ analogue to be dominant.

The $\mathrm{TiO}_{2}$ contents range from 0 to $>4$ wt. $\%$, i.e. reaching 4.3 and $4.6 \mathrm{wt} . \%$ in dumortierite from an unspecified locality in Mozambique and Rogaland, Norway, respectively (Borghi et al., 2004; Huijsmans et al., 1982), but Visser (unpublished data) obtained up to 5.10 and 5.24 wt.\% (corresponding to $0.37-0.38 \mathrm{Ti}$ p.f.u.) in two samples from Estima, Mozambique (Grew, 2002). There are two mechanisms for incorporation of $\mathrm{Ti}$ in the dumortierite group. In dumortierite containing $<0.06\left(\mathrm{Mg}+\mathrm{Fe}^{2+}\right)$ per formula unit, incorporation of Ti fits an empirical relationship $0.5 \mathrm{Ti} \rightarrow{ }^{[6]} \mathrm{Al}$ (Grew, 2002), which suggests that the substitution 
inferred for incorporation of $\mathrm{Ti}$ in the holtite group, $0.75 \mathrm{Ti}+0.25 \square \rightarrow \mathrm{Al}$ at All to form the Ti analogue of holtite (Table 1; Fig. 5), could also contribute to $\mathrm{Ti}$ incorporation in the dumortierite group, i.e. incorporation of the $\mathrm{Ti}$ analogue of holtite in dumortierite if $\mathrm{Ti}>\left(\mathrm{Mg}+\mathrm{Fe}^{2+}\right)$ (Fig. 3b). However, it is doubtful that this substitution would be relevant for dumortierite containing more $\mathrm{Mg}$ and $\mathrm{Fe}^{2+}$. In this case, incorporation of $\mathrm{Ti}+\left(\mathrm{Mg}, \mathrm{Fe}^{2+}\right)$ for $2 \mathrm{Al}$ at the All site (Table 1, Fig. $3 a$ ) is more plausible; this substitution was cited to explain the large $\mathrm{Ti}$ contents in magnesiodumortierite, which reach 4.28 wt. $\% \mathrm{TiO}_{2}$ or $0.30 \mathrm{Ti}$ p.f.u. (Chopin et al., 1995; Ferraris et al., 1995). This Ti-rich magnesiodumortierite is one of the few examples of a dumortierite-supergroup mineral in which constituents other than $\mathrm{Al}$ have also been reported at the A12, A13 or A14 sites. Magnesium is interpreted to be incorporated at the Al4 site by the substitution ${ }^{\mathrm{Al} 4} \mathrm{Mg}+\mathrm{OH} \rightarrow{ }^{\mathrm{Al} 4} \mathrm{Al}+\mathrm{O}$, reaching about $50 \%$ replacement of $\mathrm{Al}$. The structural formula deduced by these authors, $\left(\mathrm{Mg}_{1 / 3} \mathrm{Ti}_{1 / 3} \square_{1 / 3}\right)\left(\mathrm{Al}_{0.5} \mathrm{Mg}_{0.5}\right)_{2} \mathrm{Al}_{4} \mathrm{BSi}_{3} \mathrm{O}_{16}(\mathrm{OH})_{2}$, is not a valid endmember because more than one site has multiple occupancy (Hawthorne, 2002). It can be split into three endmembers: $16.7 \%$ $\left(\mathrm{Mg}_{0.5} \mathrm{Ti}_{0.5}\right) \mathrm{Al}_{6} \mathrm{BSi}_{3} \mathrm{O}_{18}, \quad 33.3 \% \quad \square \mathrm{Al}_{6} \mathrm{BSi}_{3} \mathrm{O}_{15}$ $(\mathrm{OH})_{3}$ and $50 \% \quad\left(\mathrm{Mg}_{0.5} \mathrm{Ti}_{0.5}\right) \mathrm{Mg}_{2} \mathrm{Al}_{4} \mathrm{~B}$ $\mathrm{Si}_{3} \mathrm{O}_{16}(\mathrm{OH})_{2}$, where the last is a "titano-

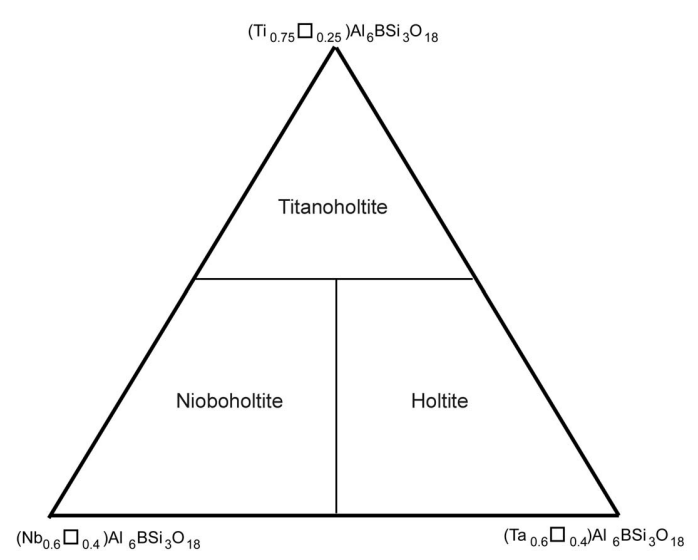

FIG. 5. Subdivision of the holtite group into one recognized mineral, holtite, and two new minerals, nioboholtite (2012-68) and titanoholtite (2012-69), on the basis of All occupancy. $\mathrm{Ti}=\left(\mathrm{Mg}, \mathrm{Fe}^{2+}\right)$ is deducted from total $\mathrm{Ti}$ to obtain the amount of $\mathrm{Ti}$ in the holtite group. magnesiodumortierite" component with $\mathrm{Mg}$ at the Al4 site unique to the Dora Maira locality.

The only substitutions reported at the $\mathrm{Si}$ sites (except $\mathrm{As}$ and $\mathrm{Sb}$, see below) involve $\mathrm{Al}^{3+}$ and $\mathrm{P}^{5+}$, reaching $0.17 \mathrm{Al}$ and $0.09 \mathrm{P}$ per formula unit (Grew, 2002; Fuchs et al., 2005), much less than the $0.49-0.51 \mathrm{Al}$ reported in dumortierite synthesized at 3-5 kbar via the substitution ${ }^{\mathrm{Si} 1,2} \mathrm{Al}+\mathrm{H}$ $\rightarrow{ }^{\mathrm{Si} 1,2} \mathrm{Si}$ (Werding and Schreyer, 1990). However, incorporation of $\mathrm{Al}$ and $\mathrm{P}$ at the $\mathrm{Si}$ sites could involve other constituents in natural dumortierite.

Dumortierite-group minerals commonly contain $\mathrm{Ta}, \mathrm{Nb}$, As and $\mathrm{Sb}$, and locally, Bi, all of which represent solid solution with holtitegroup minerals and szklaryite. Thus, calculation of the proportion of vacancies at the All site attributed to "hydroxydumortierite" must be corrected for vacancies contributed by these four constituents, as well as by Ti not associated with $\mathrm{Mg}$ and $\mathrm{Fe}^{2+}$ in the component $\left(\left[\mathrm{Mg}, \mathrm{Fe}^{2+}\right]_{0.5} \mathrm{Ti}_{0.5}\right) \mathrm{Al}_{6} \mathrm{BSi}_{3} \mathrm{O}_{18}$. The role of $\mathrm{Bi}$, presumed to be $\mathrm{Bi}^{3+}$, remains unclear because it may be too large for the (As, Sb)-like sites, and could instead substitute for $\mathrm{Al}^{3+}$ at the All site (Groat et al., 2012).

No other constituent has been reported in amounts of $>0.1 \mathrm{wt} . \%$ and usually mostly well below, e.g. $\mathrm{Be}, \mathrm{F}, \mathrm{Na}, \mathrm{K}, \mathrm{Ca}, \mathrm{Cr}, \mathrm{Mn}$ and $\mathrm{Zr}$ (Grew, 2002; Fuchs et al., 2005; Groat et al., 2012).

\section{Holtite group}

There are now three minerals in the holtite group, holtite, endmember composition $\left(\mathrm{Ta}_{0.6} \square_{0.4}\right) \mathrm{Al}_{6}$ $\mathrm{BSi}_{3} \mathrm{O}_{18}$, nioboholtite (IMA 2012-68), endmember composition $\left(\mathrm{Nb}_{0.6} \square 0.4\right) \mathrm{Al}_{6} \mathrm{BSi}_{3} \mathrm{O}_{18}$, and titanoholtite (IMA 2012-69), endmember composition ( $\left.\mathrm{Ti}_{0.75} \square_{0.25}\right) \mathrm{Al}_{6} \mathrm{BSi}_{3} \mathrm{O}_{18}$ (Fig. 5); the latter two minerals are described in Pieczka et al. (2013). Figure 3 shows that the basis for recognizing the holtite group is valency-imposed double site-occupancy in which $\mathrm{Ta}^{5+}, \mathrm{Nb}^{5+}$ and $\mathrm{Ti}^{4+}$ are paired with $\square$ in proportions to give a total valence of 3 , whereas Fig. 5 shows that division within the group is based on the dominant-valency rule.

Iron contents are generally small, not exceeding 0.77 wt.\% FeO in dumortierite-supergroup minerals at Szklary (Pieczka et al., 2011) and generally less, whereas $\mathrm{MgO}$ contents are negligible. Thus, the most abundant component in dumortierite-group minerals would be 
A $1 \mathrm{Al}_{6} \mathrm{BSi}_{3} \mathrm{O}_{18}$, with subordinate $\square \mathrm{Al}_{6} \mathrm{BSi}_{3} \mathrm{O}_{15}(\mathrm{OH})_{3}$ contributing the $\mathrm{OH}$ found in holtite-group minerals. Compositions containing $\mathrm{Sb}^{3+}$ and $\mathrm{As}^{3+}$ are relatively abundant, and for this reason, $\mathrm{Sb}^{3+}$ and $\mathrm{As}^{3+}$ have previously been considered essential for distinguishing holtite from dumortierite. There is some crystallographic basis for this inference. In the absence of $\mathrm{Sb}^{3+}$ (and $\mathrm{As}^{3+}$ ) substitution for $\mathrm{Si}$, the Al1-All distance is too short to allow $\mathrm{Ta}^{5+}$ or $\mathrm{Nb}^{5+}\left(\right.$ or $\left.\mathrm{Ti}^{4+}\right)$ at adjacent $\mathrm{All}$ positions, i.e. All positions containing $\mathrm{Ta}^{5+}$ or $\mathrm{Nb}^{5+}$ (or $\mathrm{Ti}^{4+}$ ) must be preceded and followed by vacant Al1 sites (Groat et al., 2009). These authors suggested that in holtite the vacancies due to $\mathrm{Sb}^{3+} \rightarrow \mathrm{Si}$ substitution may provide enough separation between $\mathrm{Ta}^{5+}$ or $\mathrm{Nb}^{5+}$ (or $\mathrm{Ti}^{4+}$ ) to stabilize the channel without introducing additional vacancies. However, compositions of holtite (Groat et al., 2009; Pieczka et al., 2011; Galliski et al., 2012) show only crude correlation between $\mathrm{Ta}^{5+}$ or $\mathrm{Nb}^{5+}$ (or $\mathrm{Ti}^{4+}$ ) on the one hand and $\mathrm{Sb}^{3+}$ and $\mathrm{As}^{3+}$ on the other. Because this correlation is not well defined, we recommend distinguishing vacancies introduced without $(\mathrm{Sb}, \mathrm{As})^{3+} \rightarrow \mathrm{Si}$ from vacancies introduced with $(\mathrm{Sb}, \mathrm{As})^{3+} \rightarrow \mathrm{Si}$ by recognizing a new group in the new classification.

\section{Szklaryite - a new mineral from Szklary and a potential group}

Szklaryite (IMA 2012-70), endmember formula $\square \mathrm{Al}_{6} \mathrm{BAs}_{3}^{3+} \mathrm{O}_{15}$, is the first mineral isostructural with dumortierite to contain more $\left(\mathrm{Sb}^{3+}\right.$ and $\left.\mathrm{As}^{3+}\right)$ than Si (Pieczka et al., 2011, 2013), and, according to the dominant-valency rule, qualifies as a distinct mineral (Hatert and Burke, 2008). An $\mathrm{Sb}^{3+}$ analogue to the new mineral has not yet been discovered. However, many minerals called holtite contain more $\mathrm{Sb}^{3+}$ than $\mathrm{As}^{3+}$ (Pryce, 1971; Voloshin et al., 1987; Groat et al., 2009; Pieczka et al., 2011), and thus the component $\square \mathrm{Al}_{6} \mathrm{BSb}_{3}^{3+} \mathrm{O}_{15}$ plays a major role in the dumortierite supergroup, and has been listed in Table 1 and included in Fig. 3.

Although the potential new group is distinguished by the mechanism introducing vacancies at the All site, the primary criterion for identifying minerals in the potential group is based on occupancy of the $\mathrm{Si} / \mathrm{As}, \mathrm{Sb}$ sites: $\left(\mathrm{As}^{3+}+\right.$ $\left.\mathrm{Sb}^{3+}\right)>\mathrm{Si}^{4+}$ consistent with the dominant-valency rule. That is, vacancies introduced by the substitutions ${ }^{\mathrm{All}} \square+3(\mathrm{As}, \mathrm{Sb})^{3+} \rightarrow{ }^{\mathrm{All}} \mathrm{Al}+$
$3 \mathrm{Si}^{4+}$ can be dominant at Al1 in some compositions for which $\left(\mathrm{As}^{3+}+\mathrm{Sb}^{3+}\right)<\mathrm{Si}^{4+}$.

Szklaryite is also noteworthy for its small content of $\left(\mathrm{Ta}^{5+}+\mathrm{Nb}^{5+}+\mathrm{Ti}^{4+}\right)$, which underscores the observation noted above that $\left(\mathrm{Ta}^{5+}+\right.$ $\left.\mathrm{Nb}^{5+}+\mathrm{Ti}^{4+}\right)$ and $\left(\mathrm{Sb}^{3+}+\mathrm{As}^{3+}\right)$ are poorly correlated. Indeed, in cases where $\mathrm{Si}$ is nearly entirely replaced by $\mathrm{Sb}^{3+}$ and $\mathrm{As}^{3+}$, All should be nearly vacant, and very little $\mathrm{Ta}^{5+}, \mathrm{Nb}^{5+}$ or $\mathrm{Ti}^{4+}$ could be accommodated. Conversely, if occupancy of All by $\left(\mathrm{Ta}^{5+}+\mathrm{Nb}^{5+}\right)$ approaches $60 \%$ (or $75 \%$ if $\mathrm{Ti}^{4+}$ were dominant), then very little substitution of $\mathrm{Si}$ is possible. For these reasons, a separate grouping is needed to account for the compositional variations in the dumortierite supergroup.

\section{Applying the classification}

Table 2 and Fig. 6 give the set of the compositional variables, including vacancy, which we recommend using to identify the group and species to which a particular mineral belongs. However, application of this classification requires firm knowledge of the occupancy of the cation and anion sites, particularly the All site, which necessitates single-crystal structure refinement (SREF), supplemented by spectroscopic data on iron valence and $\mathrm{H}_{2} \mathrm{O}$ content. Even with a complete dataset, full characterization of dumortierite-supergroup minerals is a challenge. Only B is present in a stoichiometric amount, whereas total octahedral cations, total anions and hydroxyl content are all non-stoichiometric. Complicating interpretation of site occupancy from SREF is the presence of several cations at the partially occupied Al1 site, i.e. Ta, Nb, Ti and $\mathrm{Al}$, which are impossible to distinguish unless SREF is combined with electron probe microanalysis.

Unfortunately, in most cases neither the necessary instrumentation nor suitable material is available for complete characterization, and thus in order to apply the classification, simplifying assumptions will have to be made. The present recommendations are for users with only electron microprobe data at hand. The simpler case is dumortierite containing little Ta, $\mathrm{Nb}, \mathrm{As}, \mathrm{Sb}$ and Bi. Hydroxyl content must be assumed, e.g. $0.75 \mathrm{OH}$ p.f.u. (Moore and Araki, 1978) or 0.40 p.f.u. (Alexander et al., 1986) for $\mathrm{Mg}$-poor dumortierite, but more $\mathrm{OH}$ for $\mathrm{Mg}$ bearing dumortierite, i.e. one $\mathrm{OH}$ for each $\mathrm{Mg}$ $(\mathrm{OH}$ was assumed to be absent in dumortierite 
TABLE 2. Compositional variables used for plotting.

$\mathrm{Ti}>\left(\mathrm{Mg}+\mathrm{Fe}^{2+}\right)$

$\mathrm{Ti}<\left(\mathrm{Mg}+\mathrm{Fe}^{2+}\right)$

\section{Dumortierite}

$\mathrm{Fe}^{3+}$ analogue of dumortierite

Magnesiodumortierite

$\mathrm{Fe}^{2+}$ analogue of dumortierite

$\mathrm{Mg}$-Ti analogue of dumortierite

$\mathrm{Fe}^{2+}-\mathrm{Ti}$ analogue of dumortierite

"Hydroxydumortierite"

\section{Holtite \\ Nioboholtite \\ Titanoholtite}

\section{Szklaryite}

$\mathrm{Sb}$ analogue of szklaryite

Bold - Mineral approved by the IMA Commission. ${ }^{\S} \mathrm{OH}$ was assumed to be absent in the compositions plotted in Fig. 7. ${ }^{\dagger}$ Amount of vacancy introduced at All by the addition of these constituents. ${ }^{*}$ Vacancy introduced at Al1 is included in the quantities of these constituents.

compositions plotted in Fig. 7a). A second simplifying assumption is that the difference between total cations and the maximum possible, 11 p.f.u., gives the vacancy at Al1; other sites are presumed to be fully occupied. In the absence of spectroscopic information, Fe valence must be assumed, but associated minerals could provide guidance, e.g. association with minerals containing only $\mathrm{Fe}^{2+}$ is strong reason to presume
$\mathrm{Fe}$ is $\mathrm{Fe}^{2+}$ in dumortierite (Pieczka, 2010; Pieczka et al., 2011).

In the cases of minerals in the dumortierite supergroup containing substantial $\mathrm{Ta}, \mathrm{Nb}, \mathrm{As}, \mathrm{Sb}$ and/or $\mathrm{Bi}$, the situation is more complex. We recommend a modification of the approach adopted by Pieczka et al. (2011) based on a simplified version of the formula derived by Groat et al. (2009). Assuming 1.000 B p.f.u. and the
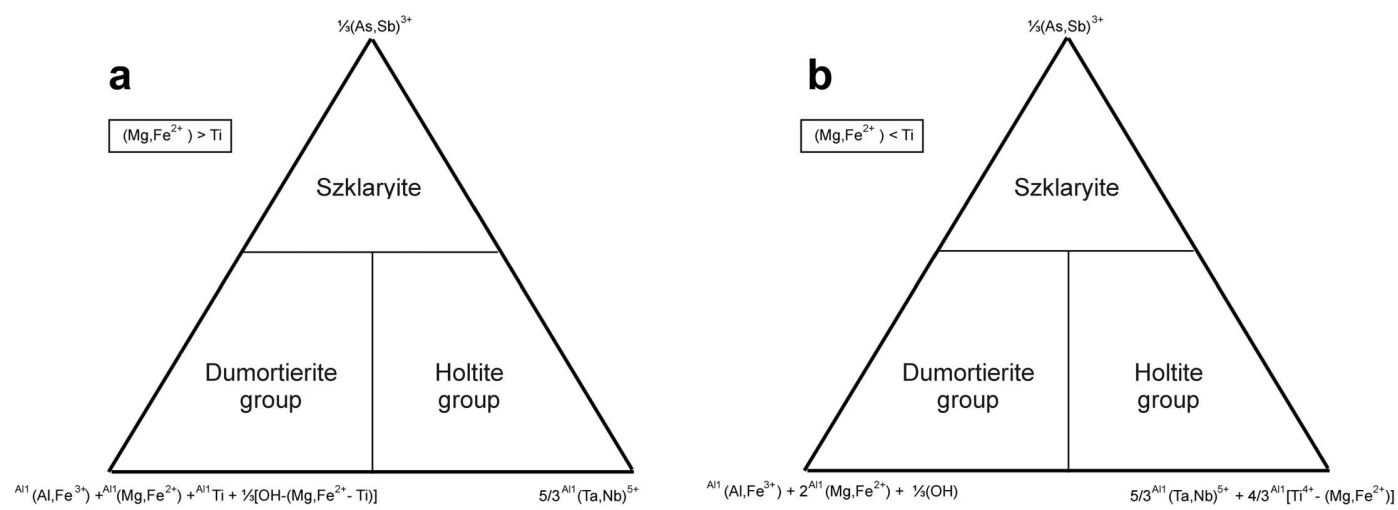

FIG. 6. Diagram of the dumortierite-supergroup showing the constituents used to plot compositions for determining group and species. 

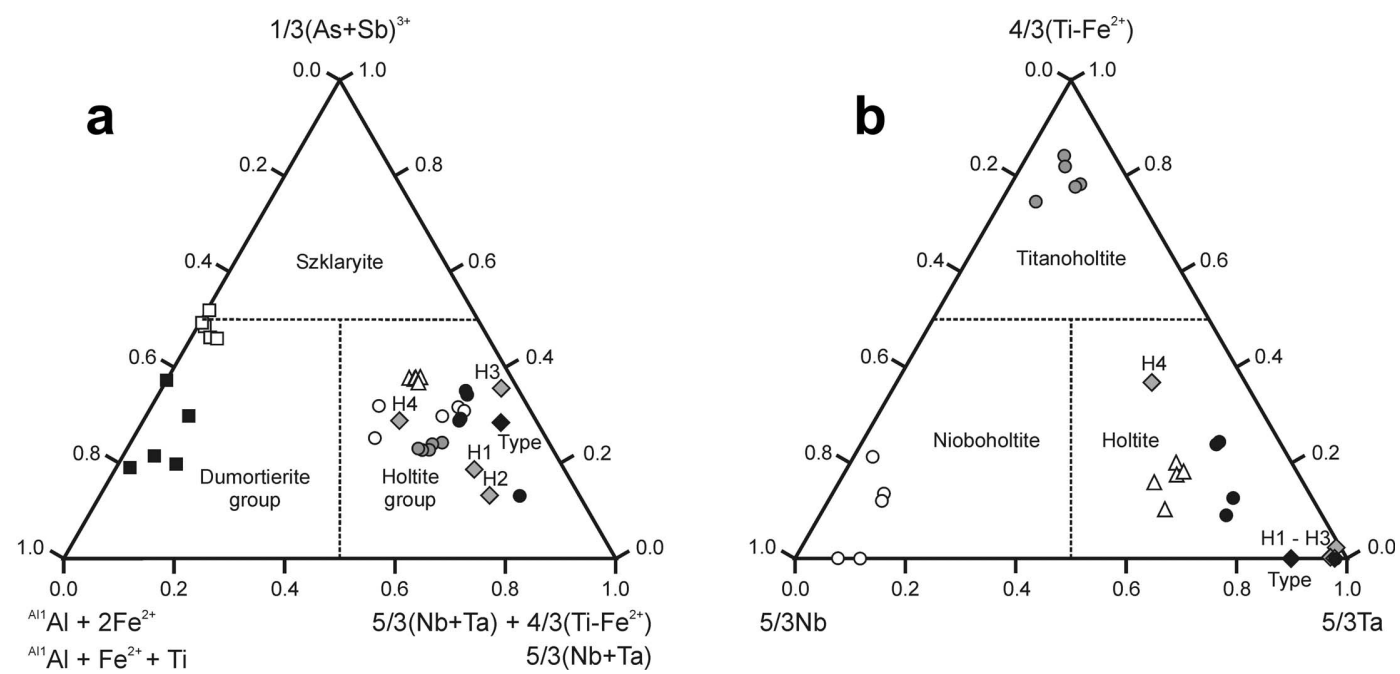

FIG. 7. Plots of selected dumortierite-supergroup minerals from the Szklary pegmatite (Pieczka et al., 2011) in the ternary system for the three groups in the dumortierite supergroup $(a)$; and in the ternary system for the holtite group $(b)$. The dumortierite-group component with $\mathrm{Fe}_{0.5}^{2+} \mathrm{Ti}_{0.5}$ is deducted from total $\mathrm{Ti}$ to get the amount of $\mathrm{Ti}$ present as titanoholtite. Symbols: $\square-(\mathrm{As}+\mathrm{Sb})$-bearing dumortierite; $\square-$ szklaryite and dumortierite approaching szklaryite in composition; $\bigcirc, \bigcirc$ and $\bigcirc$ holtite, nioboholtite and titanoholtite, respectively; $\triangle-$ the Sb-richest holtite; $\diamond-$ type holtite (Pryce, 1971); $\diamond-$ holtite H1, H2, H3 and H4 from Groat et al. (2009).

absence of $\mathrm{OH}$, then these authors' formula simplifies to $\mathrm{Al}_{7-(5 x+4 w+y) / 3}(\mathrm{Ta}, \mathrm{Nb})_{x} \mathrm{Ti}_{w}$ $\square(2 x+w+y) / 3 \mathrm{BSi}_{(3-y)}(\mathrm{Sb}, \mathrm{As})_{y} \mathrm{O}_{18-y}$, i.e. analyses should be normalized on the basis of $\mathrm{O}=$ $(18-\mathrm{As}-\mathrm{Sb})$ a.p.f.u. Vacancies have not been reported at the $\mathrm{Si}$ or $(\mathrm{As}, \mathrm{Sb})$ sites, but normalizing formulae by assuming $\mathrm{Si}+\mathrm{P}+\mathrm{As}+\mathrm{Sb}=$ 3 a.p.f.u. is not recommended despite the iteration involved, because ${ }^{[4]} \mathrm{Al}$ can substitute for $\mathrm{Si}$ not only in dumortierite, but also in some holtite (Groat et al., 2009). Assuming $\mathrm{OH}$ is absent is a major simplification of holtite composition because FTIR spectra clearly show its presence in samples from Greenbushes, Australia and Szklary (Groat et al., 2009), whereas Voloshin et al. $(1977,1987)$ reported infrared evidence for $\mathrm{H}_{2} \mathrm{O}$ and $\mathrm{OH}$ in holtite from Voron'i Tundra, Russia. Moreover, incorporation of ${ }^{\mathrm{IV}} \mathrm{Al}$ could require incorporation of $\mathrm{OH}$ for charge balance, as in the case of dumortierite (Werding and Schreyer, 1990), as would incorporation of $\left(\mathrm{Mg}, \mathrm{Fe}^{2+}\right)$ in excess of Ti. Nonetheless, we think the assumption of negligible $\mathrm{OH}$ content is justified, because Groat et al. (2009) reported that charge-balance calculations based on their singlecrystal structure refinements give results consistent with essentially no water being present. In other words, assuming holtite is anhydrous gives formulae in good agreement with site populations determined in the structure refinements.

The recommended procedure for obtaining a formula of a dumortierite-supergroup mineral from an electron microprobe analysis is as follows:

(1) Calculate a formula on the basis of $\mathrm{O}=(18$ $\mathrm{As}-\mathrm{Sb})$ or $\mathrm{O}=(18-\mathrm{As}-\mathrm{Sb}-\mathrm{Bi})$, if $\mathrm{Bi}^{3+}$ is present

(2) Assume B is stoichiometric at 1 B p.f.u.

(3) Ideally, $\mathrm{Si}+\mathrm{P}+\mathrm{As}+\mathrm{Sb}=3$, filling the $\mathrm{Sil}$ and $\mathrm{Si} 2$ sites or their $\mathrm{As}^{3+}$ and $\mathrm{Sb}^{+3}$ equivalents. In cases where the sum $\mathrm{Si}+\mathrm{P}+\mathrm{As}+\mathrm{Sb}<3$ a.p.f.u., add $\mathrm{Al}$ to get $\mathrm{Si}+\mathrm{P}+\mathrm{As}+\mathrm{Sb}+{ }^{\mathrm{IV}} \mathrm{Al}=3$ a.p.f.u.

(4) Assume A12, Al3 and Al4 are fully occupied by Al, for a total of $6 \mathrm{Al}$ p.f.u. Only in magnesiodumortierite has another cation been reported at these sites.

(5) Remaining Al, i.e. $\Sigma \mathrm{Al}-{ }^{\mathrm{IV}} \mathrm{Al}-6 \mathrm{Al}$, is assigned to All, together with $\mathrm{Mg}, \mathrm{Ti}, \mathrm{Fe}, \mathrm{Nb}$ and $\mathrm{Ta}$

(6) If $\mathrm{Nb}$ and $\mathrm{Ta}$ are very subordinate at $\mathrm{All}$, it is likely the mineral contains significant $\mathrm{OH}$; the formula should recalculated on a different basis, e.g. $\mathrm{O}=(17.625-\mathrm{As}-\mathrm{Sb})$ to allow for $0.75 \mathrm{OH}$ p.f.u. (Moore and Araki, 1978).

(7) Iron valence could be estimated from context, e.g. valence of $\mathrm{Fe}$ in associated minerals

(8) If $\mathrm{Fe}$ is assumed to be trivalent, then it is present as the $\mathrm{Fe}^{3+} \mathrm{Al}_{6} \mathrm{BSi}_{3} \mathrm{O}_{18}$ endmember 
(9) If $\mathrm{Fe}$ is assumed to be divalent and $\mathrm{Ti} \leqslant$ $\left(\mathrm{Fe}^{2+}+\mathrm{Mg}\right)$, combine the divalent components with $\mathrm{Ti}$ to form $\left(\mathrm{Fe}_{0.5}^{2+} \mathrm{Ti}_{0.5}\right) \mathrm{Al}_{6} \mathrm{BSi}_{3} \mathrm{O}_{18}$ and $\left(\mathrm{Mg}_{0.5} \mathrm{Ti}_{0.5}\right) \mathrm{Al}_{6} \mathrm{BSi}_{3} \mathrm{O}_{18}$ and the excess $\mathrm{Mg}$ and $\mathrm{Fe}^{2+}$ are present as $\mathrm{MgAl}_{6} \mathrm{BSi}_{3} \mathrm{O}_{17}(\mathrm{OH})$ and $\mathrm{Fe}^{2+} \mathrm{Al}_{6} \mathrm{BSi}_{3} \mathrm{O}_{17}(\mathrm{OH})$, respectively. If significant amounts of these components are present, the formula should be calculated on a new $\mathrm{O}$ basis, allowing for additional $\mathrm{OH}$ with $\mathrm{Mg}$ and $\mathrm{Fe}^{2+}$.

(10) If $\mathrm{Ti} \geqslant\left(\mathrm{Fe}^{2+}+\mathrm{Mg}\right)$, then include $\mathrm{Ti}$ in excess of $\left(\mathrm{Mg}+\mathrm{Fe}^{2+}\right)$ as $\left(\mathrm{Ti}_{0.75} \square_{0.25}\right) \mathrm{Al}_{6} \mathrm{BSi}_{3} \mathrm{O}_{18}$

(11) Steps 5, 8, 9 and 10 will give the relative proportion of the endmembers, which can be used to plot in Fig. 3 or 6 to identify group, then in Fig. 4 or 5 to identify species.

Analysis 4, Sz34/54, from Pieczka et al. (2011) can serve as an example of this procedure. The calculated formula is:

$\left(\square_{0.37} \mathrm{Al}_{0.24} \mathrm{Ti}_{0.31} \mathrm{Nb}_{0.04} \mathrm{Ta}_{0.03} \mathrm{Fe}_{0.01}\right)_{\Sigma 1.00} \mathrm{Al}_{6} \mathrm{~B}$ $\left(\mathrm{Si}_{2.29} \mathrm{Sb}_{0.51} \mathrm{As}_{0.19} \mathrm{Al}_{0.01}\right)_{\Sigma 3.00}\left(\mathrm{O}_{17.30} \square_{0.70}\right)_{\Sigma 18.00}$

Given the relatively large $\mathrm{Ti}$ and small $\mathrm{Mg}$ and $\mathrm{Fe}$ content, $\mathrm{OH}$ is assumed to be 0 and the formula was calculated for $\mathrm{O}=18-\mathrm{Sb}-\mathrm{As}=$ 17.30. $\mathrm{Si}>(\mathrm{As}+\mathrm{Sb})$, so the mineral is in the dumortierite or holtite group. Rearranging the contents at the All in terms of the endmembers and assuming $\mathrm{Fe}$ is ferrous, we get in decreasing abundance: $\mathrm{All}=\left\{\left(\mathrm{Ti}_{0.30} \square_{0.10}\right)\left(\mathrm{Al}_{0.24}\right)\left(\square_{0.22}\right)\right.$ $\left.\left(\mathrm{Nb}_{0.04} \square_{0.03}\right)\left(\mathrm{Ta}_{0.03} \square_{0.02}\right)\left(\mathrm{Fe}_{0.01}^{2+} \mathrm{Ti}_{0.01}\right)\right\}_{\Sigma 1.00}$

That is: $40 \%\left(\mathrm{Ti}_{0.75} \square_{0.25}\right) \mathrm{Al}_{6} \mathrm{BSi}_{3} \mathrm{O}_{18}, 24 \%$ $\mathrm{AlAl}_{6} \mathrm{BSi}_{3} \mathrm{O}_{18}, \quad 17 \% \quad \square \mathrm{Al}_{6} \mathrm{BSb}_{3}^{3+} \mathrm{O}_{15}, \quad 6 \%$ $\square \mathrm{Al}_{6} \mathrm{BAs}_{3}^{3+} \mathrm{O}_{15}, 7 \%\left(\mathrm{Nb}_{0.6} \square \square_{0.4}\right) \mathrm{Al}_{6} \mathrm{BSi}_{3} \mathrm{O}_{18}, 5 \%$ $\left(\mathrm{Ta}_{0.6} \square_{0.4}\right) \mathrm{Al}_{6} \mathrm{BSi}_{3} \mathrm{O}_{18}$ and $2 \%\left(\mathrm{Fe}_{0.5}^{2+} \mathrm{Ti}_{0.5}\right)$ $\mathrm{Al}_{6} \mathrm{BSi}_{3} \mathrm{O}_{18}, \quad \Sigma=101 \%$. Allowing for the dominant valency rule, whereby the two endmembers with $\square$ and $R^{5+}$ at All must be considered together (Hatert and Burke, 2008), the ( $\left.\mathrm{Ti}_{0.75} \square_{0.25}\right) \mathrm{Al}_{6} \mathrm{BSi}_{3} \mathrm{O}_{18}$ component is dominant, and the mineral is titanoholtite.

\section{Summary of conclusions and recommendations}

We recommend a classification based on the octahedral All site with three hierarchal levels: a dumortierite supergroup which comprises the dumortierite and holtite groups, plus a potential group not yet named, and six approved mineral species, dumortierite, magnesiodumortierite, holtite, nioboholtite, titanoholtite and szklaryite.

A new classification of the dumortierite group is necessitated by the blurring of the distinction between holtite and dumortierite, a situation arising from the term holtite being applied indiscriminately to an ever-widening compositional range, while dumortierite was found to contain substantial amounts of the elements that supposedly distinguish holtite from dumortierite.

Compositions of holtite show only crude correlation between $\mathrm{Ta}^{5+}$ or $\mathrm{Nb}^{5+}$ (or $\mathrm{Ti}^{4+}$ ) on the one hand and $\mathrm{Sb}^{3+}$ and $\mathrm{As}^{3+}$ on the other. That this correlation is not well defined is a second rationale for recognizing a new group in the new classification, i.e. distinguishing vacancies at the All site introduced without $(\mathrm{Sb}, \mathrm{As})^{3+} \rightarrow \mathrm{Si}$ (holtite group) and vacancies introduced with $(\mathrm{Sb}, \mathrm{As})^{3+} \rightarrow \mathrm{Si}$ (new group).

Thirteen endmembers are needed to account for variations in the major constituents in the minerals of the dumortierite supergroup.

\section{Acknowledgements}

We thank Jan Kihle and Diederik Visser for unpublished analyses of dumortierite and Andrew Locock for a draft of the tetrahedron in Fig. 4 (adapted from Grew et al., 2013). Members of the IMA CNMNC and two anonymous reviewers are thanked for their comments on earlier versions of this manuscript. ESG is supported by US National Science Foundation grant EAR 0837980 to the University of Maine; AP is supported by AGH UST grant no 11.11.140.319; RJE and LAG by an NSERC Discovery grant to LAG; GRR by NSF grant EAR-0947956.

\section{References}

Alexander, V.D., Griffen, D.T. and Martin, J.T. (1986) Crystal chemistry of some Fe- and Ti-poor dumortierites. American Mineralogist, 71, 786-794.

Applin, K.R. and Hicks, B.D. (1987) Fibers of dumortierite in quartz. American Mineralogist, 72, 170-172.

Bertrand, E. (1880) Sur un minéral bleu de Chaponost, près Lyon. Sur un autre minéral bleu du Chili. Bulletin de la Société Française de Minéralogie, 3, $171-172$.

Borghi, A., Cossio, R., Fiori, L., Olmi, F. and Vaggelli, G. (2004) Chemical determination of colored zoned minerals in 'natural stones' by EDS/WDS electron microprobe: an example from dumortierite quartzites. X-ray Spectrometry, 33, 21-27.

Cempírek, J. and Novák, M. (2005) A green dumortierite from Kutná Hora region, Czech Republic: spectroscopic and structural study. Crystallization Processes in Granitic Pegmatites. Elba, Italy, 4-5.

Cempírek, J., Novák, M., Dolníček, Z., Kotková, J. and Škoda, R. (2010) Crystal chemistry and origin of 
grandidierite, ominelite, boralsilite, and werdingite from the Bory Granulite Massif, Czech Republic. American Mineralogist, 95, 1533-1547.

Chopin, C., Klaska, R., Medenbach, O. and Dron, D. (1986) Ellenbergerite, a new high-pressure $\mathrm{Mg}-\mathrm{Al}-(\mathrm{Ti}, \mathrm{Zr})$-silicate with a novel structure based on face-sharing octahedra. Contributions to Mineralogy and Petrology, 92, 316-321.

Chopin, C., Ferraris, G., Ivaldi, G., Schertl, H.-P., Schreyer, W., Compagnoni, R., Davidson, C. and Davis, A.M. (1995) Magnesiodumortierite, a new mineral from very-high-pressure rocks (western Alps). II. Crystal chemistry and petrological significance. European Journal of Mineralogy, 7, 525-535.

Claringbull, G.F. and Hey, M.H. (1958) New data for dumortierite. Mineralogical Magazine, 31, 901-907.

Evans, R.J. and Groat, L.A. (2012) Structure and topology of dumortierite and dumortierite-like materials. The Canadian Mineralogist, 50, 1197-1231.

Evans, R.J., Fyfe, C.A., Groat, L.A. and Lam, A.E. (2012) MAS NMR measurements and ab initio calculations of the ${ }^{29} \mathrm{Si}$ chemical shifts in dumortierite and holtite. American Mineralogist, 97, 329-340.

Farges, F., Galoisy, L., Balan, E., Fuchs, Y. and Linarès, J. (2004) Structure and color of the Jack Creek dumortierite (Montana, USA) using spectroscopic approaches. Mitteilungen der Österreichischen Mineralogischen Gesellschaft, 149, 29.

Ferraris, G., Ivaldi, G. and Chopin, C. (1995) Magnesiodumortierite, a new mineral from veryhigh-pressure rocks (Western Alps). Part I: Crystal structure. European Journal of Mineralogy, 7, $167-174$.

Fleet, M.E. and Muthupari, S. (2000) Boron $K$-edge XANES of borate and borosilicate minerals. American Mineralogist, 85, 1009-1021.

Fuchs, Y., Balan, E., Farges, F., Linarès, J. and Horn, A. (2004) Fe and Ti in dumortierite: A FTIR, EPR, Mössbauer and Fe/Ti K-edge XANES study. Lithos, 73 (Supplement), S39.

Fuchs, Y., Ertl, A., Hughes, J. M., Prowatke, S., Brandstaetter, F. and Schuster, R. (2005) Dumortierite from the Gföhl unit: Lower Austria; chemistry, structure, and infra-red spectroscopy. European Journal of Mineralogy, 17, 173-183.

Galliski, M.A., Márques-Zavalía, M.F., Lira, R., Cempírek, J. and Škoda, R. (2012) Mineralogy and origin of the dumortierite-bearing pegmatites of Virorco, San Luis, Argentina. The Canadian Mineralogist, 50, 873-894.

Garvie, L.A.J., Craven, A.J. and Brydson, R. (1995) Parallel electron energy-loss spectroscopy (PEELS) study of $\mathrm{B}$ in minerals: The electron energy-loss near-edge structure (ELNES) of the B $K$ edge. American Mineralogist, 80, 1132-1144.

Golovastikov, N.I. (1965) The crystal structure of dumortierite. Doklady Akademii Nauk SSSR, 162, 1284-1287 (in Russian, English translation, Soviet Physics Doklady, 10, 493-495).

Gonnard, M.F. (1881) Note sur l'existence d'une espèce minérale nouvelle, la dumortiérite dans le gneiss de Beaunan, au-dessus des anciens aqueducs galloromains de la vallée de l'Izeron (Rhône). Bulletin de la Société Française de Minéralogie, 4, 2-5.

Goreva, J.S. and Rossman, G.R. (2000) A blue variety of rose quartz. Geological Society of America Abstracts with Programs, 32(7), A-439 - A-440.

Goreva, J.S., Ma, C. and Rossman, G.R. (2001) Fibrous nanoinclusions in massive rose quartz: The source of rose coloration. American Mineralogist, 86, 466-472.

Grew, E.S. (2002) Borosilicates (exclusive of tourmaline) and boron in rock-forming minerals in metamorphic environments. Pp. 387-502 in: Boron: Mineralogy, Petrology, and Geochemistry (L.M. Anovitz and E.S. Grew, editors). Reviews in Mineralogy, 33, Mineralogical Society of America, Washington, D.C.

Grew, E.S., Locock, A.J., Mills, S.J, Galuskina, I.O., Galuskin, E.V. and Hålenius, U. (2013) Nomenclature of the garnet supergroup. American Mineralogist, 98, 785-811.

Groat, L.A., Grew, E.S., Ercit, T.S. and Pieczka, A. (2001): The crystal chemistry of dumortierite and holtite, aluminoborosilicates with heavy elements. Geological Society of America Abstracts with Programs, 33(6), A-383.

Groat, L.A., Grew, E. S., Evans, R.J., Pieczka, A. and Ercit, T.S. (2009) The crystal chemistry of holtite. Mineralogical Magazine, 73, 1033-1050.

Groat, L.A., Evans, R.J., Grew, E.S. and Pieczka, A. (2012) Crystal chemistry of As and Sb-bearing dumortierite. The Canadian Mineralogist, 50, $855-872$.

Hatert, F. and Burke, E.A.J. (2008) The IMA-CNMNC dominant-constituent rule revisited and extended. The Canadian Mineralogist, 46, 717-728.

Hawthorne, F.C. (2002) The use of end-member chargearrangements in defining new mineral species and heterovalent substitutions in complex minerals. The Canadian Mineralogist, 40, 699-710.

Hoskins, B.F., Mumme, W.G. and Pryce, M.W. (1989) Holtite, $\left(\mathrm{Si}_{2.25} \mathrm{Sb}_{0.75}\right) \mathrm{B}\left[\left(\mathrm{Al}_{6}\left(\mathrm{Al}_{0.43} \mathrm{Ta}_{0.27} \square_{0.30}\right)\right.\right.$ $\left.\mathrm{O}_{15}(\mathrm{O}, \mathrm{OH})_{2.25}\right]$ : crystal structure and crystal chemistry. Mineralogical Magazine, 53, 457-463.

Huijsmans, J.P.P., Barton, M. and van Bergen, M.J. (1982) A pegmatite containing Fe-rich grandidierite, Ti-rich dumortierite and tourmaline from the Precambrian, high-grade metamorphic complex of 
Rogaland, S. W. Norway. Neues Jahrbuch für Mineralogie Abhandlungen, 143, 249-261.

Kazantsev, S.S., Pushcharovsky, D.Yu., Pasero, M., Merlino, S., Zubkova, N.V., Kabalov, Yu.K. and Voloshin, A.V. (2005) Crystal structure of holtite I. Crystallography Reports, 50, 42-47.

Kazantsev, S.S., Zubkova, N.V. and Voloshin, A.V. (2006) Refinement of composition and structure of holtite I. Crystallography Reports, 51, 412-413.

Keller, P. (2001) Ekatite, $\left(\mathrm{Fe}^{3+}, \mathrm{Fe}^{2+}, \mathrm{Zn}\right)_{12}$ $(\mathrm{OH})_{6}\left[\mathrm{AsO}_{3}\right]_{6}\left[\mathrm{AsO}_{3}, \mathrm{HOSiO}_{3}\right]_{2}$, a new mineral from Tsumeb, Namibia, and its crystal structure. European Journal of Mineralogy, 13, 769-777.

Kihle, J. (1989) Polymetamorphic evolution of cordierite-bearing metapelites of the Bamble-sector, Southern Norway. Unpublished Candidate of Science Thesis, Department of Geology, University of Oslo, 3 vol, $360 \mathrm{p}$ (in Norwegian).

Ma, C., Goreva, J.S. and Rossman, G.R. (2002) Fibrous nanoinclusions in massive rose quartz: HRTEM and AEM investigations. American Mineralogist, 87, 269-276.

Moore, P.B. and Araki, T. (1978) Dumortierite, $\mathrm{Si}_{3} \mathrm{~B}\left[\mathrm{Al}_{6.75} \square_{0.25} \mathrm{O}_{17.25}(\mathrm{OH})_{0.75}\right]$ : a detailed structure analysis. Neues Jahrbuch für Mineralogie Abhandlungen, 132, 231-241.

Ono, A. (1981) Synthesis of dumortierite in the system $\mathrm{Al}_{2} \mathrm{O}_{3}-\mathrm{SiO}_{2}-\mathrm{B}_{2} \mathrm{O}_{3}-\mathrm{H}_{2} \mathrm{O}$. Journal of the Japanese Association of Mineralogists, Petrologists and Economic Geologists, 76(1), 21-25.

Pieczka, A. (2010) Primary Nb-Ta minerals in the Szklary pegmatite, Poland: new insights into controls of crystal chemistry and crystallization sequences. American Mineralogist, 95, 1478-1492.

Pieczka, A. and Marszałek, M. (1996) Holtite - the first occurrence in Poland. Mineralogia Polonica, 27, 3-8.

Pieczka, A., Grew, E.S., Groat, L.A. and Evans, R.J. (2011) Holtite and dumortierite from the Szklary Pegmatite, Lower Silesia, Poland. Mineralogical Magazine, 75, 303-315.

Pieczka, A., Evans, R.J., Grew, E.S., Groat, L.A., Ma, C. and Rossman, G.R. (2013) The dumortierite supergroup. II. Three new minerals from the Szklary pegmatite, SW Poland: Nioboholtite, $\left(\mathrm{Nb}_{0.6} \square 0.4\right) \mathrm{Al}_{6} \mathrm{BSi}_{3} \mathrm{O}_{18}$, titanoholtite, $\left(\mathrm{Ti}_{0.75} \square_{0.25}\right) \mathrm{Al}_{6} \mathrm{BSi}_{3} \mathrm{O}_{18}$, and szklaryite, $\square \mathrm{Al}_{6} \mathrm{BAs}_{3}^{3+} \mathrm{O}_{15}$ Mineralogical Magazine, 77, 2841-2856.

Platonov, A.N., Langer, K., Chopin, C., Andrut, M. and Taran, M.N. (2000) $\mathrm{Fe}^{2+}-\mathrm{Ti}^{4+}$ charge-transfer in dumortierite. European Journal of Mineralogy, 12, $521-528$.
Pryce, M.W. (1971) Holtite: a new mineral allied to dumortierite. Mineralogical Magazine, 38, 21-25.

Raade, G., Rømming, C. and Medenbach, O. (1998) Carbonate-substituted phosphoellenbergerite from Modum, Norway: description and crystal structure. Mineralogy and Petrology, 62, 89-101.

Schaller, W.T. (1905) Dumortierite. In Contributions to Mineralogy from the U. S. Geological Survey, U.S. Geological Survey Bulletin, 262, 91-120 (A portion of this paper was published in American Journal of Science, 169, 211-224)

Vaggelli, G., Olmi, F., Massi, M., Giuntini, L., Fedi, M., Fiori, L., Cossio, R. and Borghi, A. (2004) Chemical investigation of colored minerals in natural stones of commercial interest. Microchimica Acta, 145, 249-254.

Visser, D. and Senior, A. (1991) Mg-rich dumortierite in cordierite-orthoamphibole-bearing rocks from the high-grade Bamble Sector, south Norway. Mineralogical Magazine, 55, 563-577.

Voloshin, A.V. and Pakhomovskiy, Ya.A. (1988) Mineralogy of Tantalum and Niobium in RareMetal Pegmatites. Nauka, Leningrad (in Russian).

Voloshin, A.V., Gordienko, V.V., Gel'man, Ye.M., Zorina, M.L., Yelina, N.A., Kul'chitskaya, Ye.A., Men'shikov, Yu.P., Polezhayeva, L.I., Ryzhova, R.I., Sokolov, P.B. and Utochkina, G.I. (1977) Holtite (first find in the USSR) and its relationship with other tantalum minerals in rare-metal pegmatites. Zapiski Vsesoyuznogo Mineralogicheskogo Obshchestva, 106(3), 337-347 (in Russian).

Voloshin, A.V., Pakhomovskiy, Ya.A. and Zalkind, O.A. (1987) An investigation of the chemical composition and IR-spectroscopy of holtite. In Mineral'nyye Assotsiatsii $i$ Mineraly Magmaticheskikh Kompleksov Kol'skogo Poluostrova, pp. 14-34 Kol'skiy Filial Akademii Nauk SSSR, Apatity (in Russian).

Vrána, S. (1979) A polymetamorphic assemblage of grandidierite, kornerupine, Ti-rich dumortierite, tourmaline, sillimanite, and garnet. Neues Jahrbuch für Mineralogie Monatshefte, 1979(1), 22-33.

Werding, G. and Schreyer, W. (1990) Synthetic dumortierite: its PTX-dependent compositional variations in the system $\mathrm{Al}_{2} \mathrm{O}_{3}-\mathrm{B}_{2} \mathrm{O}_{3}-\mathrm{SiO}_{2}-\mathrm{H}_{2} \mathrm{O}$. Contributions to Mineralogy and Petrology, 105, $11-24$.

Willner, A.P. and Schreyer, W. (1991) A dumortieritetopaz-white mica fels from the peraluminous metamorphic suite of Bushmanland (South Africa). Neues Jahrbuch für Mineralogie Monatshefte, 1991(5), 223-240. 